Research Paper

\title{
Pathological and Prognostic Impacts of FGFR2 Overexpression in Gastric Cancer: A Meta-Analysis
}

\author{
Hyeong Su Kim ${ }^{1}$, Jung Han Kim ${ }^{1}$, Hyun Joo Jang ${ }^{2}{ }^{\bowtie}$, Boram Han ${ }^{1}$, Dae Young Zang ${ }^{1}$ \\ 1. Division of Hemato-Oncology, Department of Internal Medicine, Kangnam Sacred-Heart Hospital, Hallym University Medical Center, Hallym University \\ College of Medicine, Seoul, Republic of Korea; \\ 2. Division of Gastroenterology, Department of Internal Medicine, Dongtan Sacred-Heart Hospital, Hallym University Medical Center, Hallym University \\ College of Medicine, Hwasung, Republic of Korea.
}

$\triangle$ Corresponding authors: Jung Han Kim and Hyun Joo Jang. Department of Internal Medicine, Hallym University Medical Center, Hallym University College of Medicine, Seoul, Republic of Korea. E-mail: harricil@hallym.or.kr (JH Kim), jhj1229@hallym.or.kr (HJ Jang)

(1) Ivyspring International Publisher. This is an open access article distributed under the terms of the Creative Commons Attribution (CC BY-NC) license (https:// creativecommons.org/licenses/by-nc/4.0/). See http://ivyspring.com/terms for full terms and conditions.

Received: 2018.06.29; Accepted: 2018.08.15; Published: 2019.01.01

\begin{abstract}
Fibroblast growth factor receptor-2 (FGFR2) protein expression by immunohistochemistry has been reported in up to $60 \%$ of patients with gastric cancer (GC). However, the clicopathological impacts of high FGFR2 expression have not been consistent among studies. We conducted this meta-analysis to evaluate the pathological and prognostic significance of FGFR2 overexpression in patients with GC. A systematic search of the electronic databases including PubMed, PMC, EMBASE, and Google Scholar was performed. From ten studies, 4,294 patients were included in the pooled analyses of odds ratios (ORs) with $95 \%$ confidence intervals $(\mathrm{Cls})$ for pathological features and hazard ratios (HRs) with 95\% Cls for overall survival according to the FGFR2 expression status. Compared with tumors showing low FGFR2 expression, GCs with FGFR2 overexpression revealed deeper depth of invasion ( $\mathrm{pT} 3-4)(\mathrm{OR}=2.63,95 \% \mathrm{Cl}: 1.70-4.06, \mathrm{p}<0.0001)$, higher rate of lymph node metastasis (OR = 1.87, 95\% Cl: 1.31-2.67, $\mathrm{p}<0.0001)$, and more advanced stage (III-IV) $(\mathrm{OR}=$ 1.78, 95\% Cl: 1.07-2.96, $\mathrm{p}=0.03$ ). In addition, patients with FGFR2-overexpressed GC showed significantly worse survival than those with FGFR2-low tumor $(\mathrm{HR}=1.40,95 \% \mathrm{Cl}: 1.25-1.58, \mathrm{p}<$ $0.00001)$. In conclusion, this meta-analysis indicates that FGFR2 overexpression is associated with poor pathological features and prognosis in patients with GC.
\end{abstract}

Key words: FGFR2 overexpression, gastric cancer, prognosis, meta-analysis, review

\section{Introduction}

Gastric cancer (GC) is the most frequently occurring malignancy in South Korea and fifth common cancer worldwide [1,2]. Despite the development of multidisciplinary treatments, GC is the third leading cause of cancer-related death worldwide [2]. Complete resection with or without perioperative or adjuvant treatment can provide a potential chance of cure for patients with early-stage disease. However, nearly two-thirds of newly diagnosed GC patients present with advanced or metastatic disease. Moreover, more than $60 \%$ of the patients who received radical surgery with curative intent develop recurrence within five years [3,4]. For patients with recurrent or metastatic diseases, systemic chemotherapy can prolong median overall survival (OS) from 3-4 months to approximately 10-13 months $[5,6]$. The combination of chemotherapy with trastuzumab in patients with HER2-positive advanced GC and the introduction of antiangiogenic agent (ramucirumab) or immune checkpoint inhibitor (nivolumab) as salvage therapy in non-selective patients with metastatic GC demonstrated modest survival benefits [7-9]. Despite the improved outcomes with molecular targeted therapy, however, the prognosis of advanced GC still remains poor; therefore, there is a critical need to develop more efficacious therapeutic agents.

The fibroblast growth factor (FGF) pathway is 
under active investigation as a potential therapeutic target in several types of malignancies [10-13]. FGF receptors (FGFR1-4) are transmembrane tyrosine kinase receptors [14]. FGFR2 gene is located on chromosome 10q26 and functions as FGFR; FGF binding to the monomeric receptor triggers dimerizetion and autophosphorylation of the kinase domain. The protein synonyms of FGFR2 include keratinocyte growth factor receptor (KGFR) and K-sam. This signaling pathway regulates a variety of cellular functions including cell proliferation, migration, and differentiation $[13,14]$. Therefore, dysregulation of the FGF/FGFR pathway due to gene amplification, mutations, receptor overexpression, or aberrant transcriptional regulation can be associated with cancer development and progression [15-17].

FGFR2 protein overexpression by immunochemistry (IHC) has been observed in a variety of human cancers, including esophageal cancer [18], colorectal cancer [19], pancreatic cancer [20], hepatocellular carcinoma [21], breast cancer [22], and GC [23-34]. The data suggested that FGFR2 overexpression was associated with tumor growth, vascular or lymphatic invasion, metastasis, or prognosis. However, the prognostic significance of FGFR2 overexpression in solid tumors is inconclusive. In GC, FGFR2 overexpression has been reported in up to $60 \%$ of patients [31,32]. Many studies investigated the clinicopathological findings and prognosis of GCs showing FGFR2 overexpression [23-33]. Some found that FGFR2 overexpression was associated with poor pathological features or prognosis [25,27,29-31]. However, other studies have failed to demonstrate the prognostic role of FGFR2 overexpression as an adverse predictor in patients with GC $[23,26,28,32,33]$. Furthermore, Matsunobu et al. reported that high FGFR2 expression might be associated with favorable outcomes [24].

Therefore, we performed a comprehensive metaanalysis to gain a better insight into the pathological and prognostic impacts of high FGFR2 expression in GC. The main aim of this study was to evaluate the correlation of FGFR2 overexpression with survival in patients with GC, illustrating the clinical significance of FGFR2 as a prognostic indicator and potential therapeutic target for GC.

\section{Materials and Methods}

\section{Publication search strategy}

A computerized extensive search of the online databases including PubMed, PMC, EMBASE, and Google Scholar (up to June 2018) was carried out in order to retrieve articles assessing the association of FGFR2 expression (including protein synonyms
KGFR and K-sam) and clinicopathological features in GC. The search used the following keywords variably combined: "fibroblast growth factor receptor 2" or "FGFR2" or "keratinocyte growth factor receptor" or "KGFR" or "K-sam" and "gastric cancer" or "stomach cancer." In case of duplicate publications, the recent papers were selected. The 'snowball' method was used to identify additional relevant articles and the reference lists of identified articles were also hand-searched.

\section{Eligible criteria}

Clinical studies should meet the following eligible criteria: (i) prospective or retrospective cohort study; (ii) study investigating the correlation of FGFR2 expression by IHC with pathological features [depth of tumor invasion (pT), lymph mode (LN) metastasis, and disease stage] or prognosis in patients with gastric adenocarcinoma, including adenocarcinoma of the esophagogastric junction; (iii) the use of adequate IHC method to assess FGFR2 expression status; (iv) sufficient data to estimate odds ratio (OR) with $95 \%$ confidence interval (CI) for pathological findings and/or hazard ratio (HR) with 95\% CIs for overall survival (OS); (v) studies published only in peer-reviewed journals; and (vi) articles written in English.

\section{Data extraction}

Two investigators (HSK and $\mathrm{HJJ}$ ), working independently and in parallel, screened the titles and abstracts and then reviewed the articles that appeared to meet the predefined inclusion criteria. The following data were extracted from each eligible study and recorded using the predesigned table: first author, year of publication, country, inclusion period, pathological findings ( $\mathrm{pT}$, LN metastasis, and disease stage), number of patients, detecting method and cut-off criteria for FGFR2 overexpression, and ORs with 95\% CIs for pathological findings and HRs with their 95\% CIs for OS. When both univariate and multivariate analysis were performed for OS, the HR with $95 \%$ CI from multivariate analysis was extracted.

\section{Statistical analysis}

The strength of the association between FGFR2 overexpression and pathological findings was shown as ORs with their 95\% CIs. For the survival analyses, HRs with 95\% CIs according to the FGFR2 expression status were combined. Statistical values were directly obtained from the original articles. If ORs or HRs with their 95\% CIs were not reported, the Engauge Digitizer software was utilized to calculate them from the corresponding data and Kaplan-Meier curves, respectively. The RevMan version 5.3 software was used to combine the data. The heterogeneity across 
studies was assessed by the $\mathrm{Q}$ statistics and $\mathrm{I}^{2}$ inconsistency test. If there was no significant heterogeneity ( $\mathrm{p} \geq 0.1$ and $\mathrm{I}^{2} \leq 50 \%$ ), the fixed effect model according to the Mantel-Haenszel method was used. When significant heterogeneity was observed $(p<0.1$ or $\mathrm{I}^{2}>50 \%$ ), the random-effects model based on the DerSimonian-Laird method was selected. Statistical significance of the pooled HR or OR was determined by $\mathrm{Z}$ test. The combined OR or HR $>1.0$ implies that GC harboring FGFR2 overexpression had worse pathological features or survival, respectively.

Publication biases were graphically evaluated by funnel plots, and the asymmetry of each funnel plot was quantified by the Begg's test and Egger's test [35, 36]. All the p-values were two-sided, with p-value < 0.05 considered significant.

\section{Results}

\section{Results of search}

The flow diagram of search process is shown in Figure 1. A total of 159 potentially relevant articles were initially retrieved, but 137 of them were excluded after careful screening of the titles and abstracts. Of the remaining 22 potentially eligible studies, 12 which did not meet the eligible criteria were further excluded. Finally, ten studies were selected for the current meta-analysis [23-32].

\section{Characteristics of the included studies}

The main characteristics and clinicopathological findings of the ten included studies are summarized in Table 1. All the studies were performed

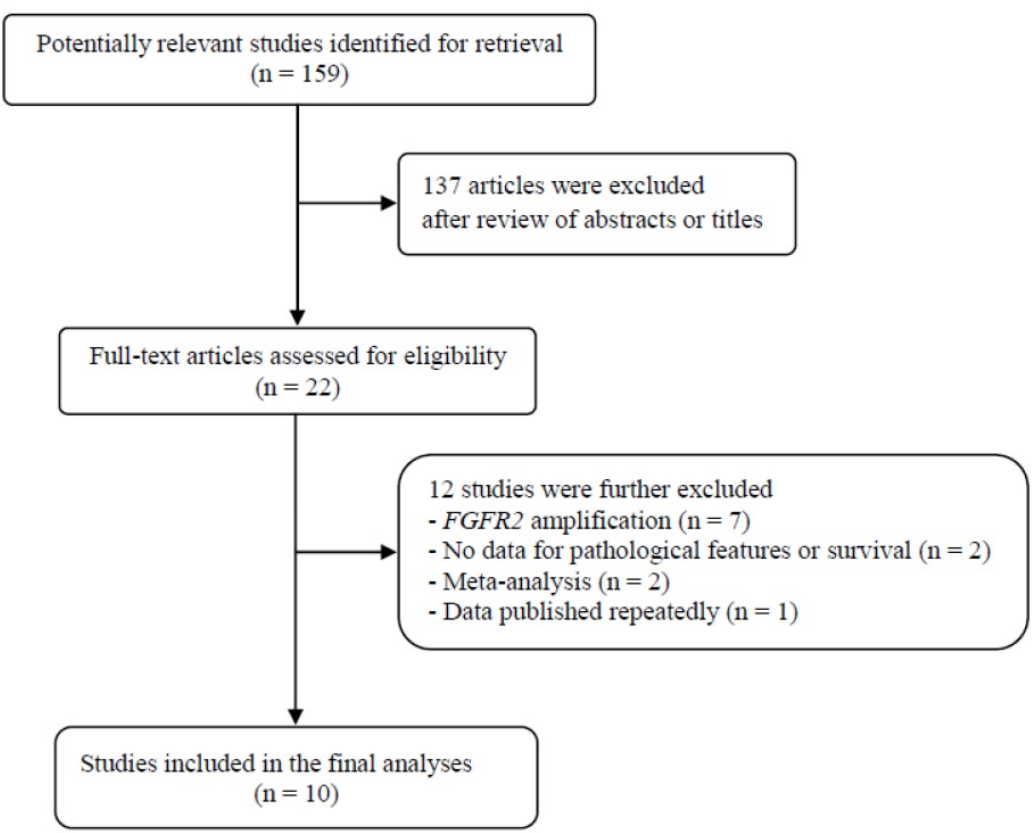

Figure 1. Flow diagram of search process retrospectively in Asian populations (from Japan, South Korea, and China). IHC method with a variety of antibodies was used to assess FGFR2 expression status, but the interpretation of IHC staining and cut-off criteria for overexpression were varied among studies. Frequencies of high FGFR2 expression in the included studies ranged from $2.5 \%$ [28] to $61.4 \%$ [31]. Five studies reported FGFR2 overexpression as a significant adverse prognostic factor [25,27,29-31]. However, the remaining five studies failed to observe statistically significant impact of high FGFR2 expression on survival in the univariate $[23,24]$ or multivariate analysis [26,28,32].

\section{Pathological impact of FGFR2 overexpression}

From six studies [25-27,29-31], 3,601 patients were included in the meta-analysis of ORs with $95 \%$ CIs for the depth of tumor invasion (pT). There was a significant heterogeneity among studies $\left(X^{2}=16.43, p\right.$ $\left.=0.006, \mathrm{I}^{2}=70 \%\right)$ and the random-effects model was used. Compared with GCs with low expression, tumors with high FGFR2 expression showed significantly deeper depth of invasion (pT3-4) $(\mathrm{OR}=2.63$, 95\% CI: 1.70-4.06, $\mathrm{p}<0.0001$ ) (Figure 2A).

From the ten studies, 4,294 patients were analyzed for the effect of FGFR2 overexpression on the LN metastasis. The random-effects model was selected because there was a significant heterogeneity across the studies $\left(X^{2}=19.71, \mathrm{p}=0.02, \mathrm{I}^{2}=54 \%\right)$. Compared with tumors having low FGFR2 expression, GCs with overexpression showed higher rate of $\mathrm{LN}$ metastasis (OR $=1.87,95 \% \mathrm{CI}: 1.31-2.67$, $\mathrm{p}<$ 0.0001) (Figure 2B).

From seven studies $[23,24,26-28,30$, 32], 2,008 patients were included in the meta-analysis to evaluate the correlation between FGFR2 overexpression and disease stage. The random-effects model was also adopted for pooling heterogeneous outcomes $\left(X^{2}=18.98, \mathrm{p}=0.004, I^{2}=\right.$ $68 \%)$. Patients with FGFR2-overexpressed GC had more advanced stage (III-IV) than those with GC showing low FGFR2 expression $(\mathrm{OR}=1.78,95 \% \mathrm{CI}$ : 1.07-2.96, $\mathrm{p}=0.03)$ (Figure 2C).

\section{Prognostic significance of FGFR2 overexpression}

From the ten studies, a total of 4,294 patients were included in the metaanalysis of HRs for OS. Compared with patients with GC showing low FGFR2 expression, patients with tumors harboring FGFR2 overexpression had significantly worse survival $(\mathrm{HR}=1.40,95 \% \mathrm{CI}$ : 
1.25-1.58, $\mathrm{p}<0.00001$ ) (Figure 3). The fixed-effect model was used because there was no significant heterogeneity among studies $\left(X^{2}=10.82, p=0.29, \mathrm{I}^{2}=\right.$ $17 \%)$.

\section{Publication bias}

We did not perform publication bias tests for $\mathrm{pT}$ and stage because a limted number of studies were included. The funnel plots of LN metastasis (Figure 4A) and OS (Figure 4B) were graphically symmetric. Additionally, Begg's test and Egger's test indicated no evidence of substantial publication bias for LN metastasis (Begg's $\mathrm{p}=0.210$, Egger's $\mathrm{p}=0.431$ ) and OS $($ Begg's $p=0.464$, Egger's $p=0.415)$.

Table 1. Summary of the ten included studies

\begin{tabular}{|c|c|c|c|c|c|c|c|c|c|c|}
\hline $\begin{array}{l}\text { First } \\
\text { author } \\
\text { (year) [ref.] }\end{array}$ & Country & $\begin{array}{l}\text { Inclusion } \\
\text { period }\end{array}$ & Stage & $\begin{array}{l}\text { No. of } \\
\text { patients }\end{array}$ & $\begin{array}{l}\text { Methods, } \\
\text { antibody }\end{array}$ & $\begin{array}{l}\text { Interpretation of IHC staining } \\
\text { (Cut-off for FGFR2 overexpression) }\end{array}$ & $\begin{array}{l}\text { FGFR2 } \\
\text { over- } \\
\text { expression } \\
(\%)\end{array}$ & $\begin{array}{l}\text { pT3-4 } \\
\text { (high : } \\
\text { low) }\end{array}$ & $\begin{array}{l}\text { LN } \\
\text { metastasis } \\
\text { (high: } \\
\text { low) }\end{array}$ & $\begin{array}{l}\text { Stage } \\
\text { III-IV } \\
\text { (high : } \\
\text { low) }\end{array}$ \\
\hline $\begin{array}{l}\text { Hattori } \\
(1996)[23]\end{array}$ & Japan & $1990-1991$ & I-IV & 38 & $\begin{array}{l}\text { IHC with whole } \\
\text { slides } \\
\text { Anti-human } \\
\text { K-sam Ab (pK1-2) }\end{array}$ & NA & $20(52.6 \%)$ & NA & $\begin{array}{l}18(90 \%): \\
15(83.3 \%) \\
p=0.32\end{array}$ & $\begin{array}{l}17(85 \%): \\
10(55.6 \%) \\
p=0.091\end{array}$ \\
\hline $\begin{array}{l}\text { Matsunobu } \\
(2006)[24]\end{array}$ & Japan & 1994-1999 & I-IV & 126 & $\begin{array}{l}\text { IHC with whole } \\
\text { slides } \\
\text { Rabbit anti-KGFR } \\
\text { PoAb }\end{array}$ & $\begin{array}{l}\text { Positive staining in more than } 10 \% \text { of tumor } \\
\text { cells. }\end{array}$ & $46(36.5 \%)$ & NA & $\begin{array}{l}22(47.8 \%) \\
: 50 \\
(62.5 \%) \\
\text { NS }\end{array}$ & $\begin{array}{l}15(32.6 \%) \\
: 44(55 \%) \\
p=0.0149\end{array}$ \\
\hline $\begin{array}{l}\text { Toyokawa } \\
(2009)[25]\end{array}$ & Japan & NA & II-IV & 136 & $\begin{array}{l}\text { IHC with whole } \\
\text { slides } \\
\text { Rabbit anti-K-sam } \\
\text { PoAb }\end{array}$ & $\begin{array}{l}\text { Positive when tumor cells at the invading } \\
\text { front }>25 \% \text { were stained more strongly than } \\
\text { normal epithelium in the same sample. }\end{array}$ & $42(30.9 \%)$ & $\begin{array}{l}38 \\
(90.5 \%): \\
68 \\
(72.3 \%) \\
p=0.018\end{array}$ & $\begin{array}{l}9(21.4 \%): \\
29(30.9 \%) \\
p=0.258\end{array}$ & NA \\
\hline $\begin{array}{l}\text { Murase } \\
(2014)[26]\end{array}$ & Japan & 2003-2009 & I-IV & 222 & $\begin{array}{l}\text { IHC with TMA, } \\
\text { Rabbit } \\
\text { anti-FGFR2 PoAb }\end{array}$ & $\begin{array}{l}\text { Intensity: } 0 \text {, no staining; } 1 \text {, weak; } 2 \text {, } \\
\text { moderate; } 3 \text {, strong. } \\
\text { Percentage of stained tumor cells: } 0 \text {, no } \\
\text { staining; } 1, \leq 20 \% ; 2,>20 \text { to } \leq 50 \% ; 3,>50 \% \text { of } \\
\text { tumor cells. } \\
\text { (FGFR2 overexpression: intensity score }+ \\
\text { percentage score } \geq 4 \text { ). }\end{array}$ & $\begin{array}{l}114 \\
(51.4 \%)\end{array}$ & $\begin{array}{l}63 \\
(55.3 \%): \\
41(38 \%) \\
p=0.011\end{array}$ & $\begin{array}{l}65(57 \%): \\
43(39.8 \%) \\
p=0.011\end{array}$ & $\begin{array}{l}52(45.6 \%) \\
: 30 \\
(27.8 \%) \\
p=0.012\end{array}$ \\
\hline $\begin{array}{l}\text { Nagatsuma } \\
\text { (2015) [27] }\end{array}$ & Japan & 2003-2007 & I-IV & 950 & $\begin{array}{l}\text { IHC with TMA } \\
\text { Rabbit } \\
\text { anti-FGFR2 PoAb } \\
\text { (sc-122) }\end{array}$ & $\begin{array}{l}\text { Intensity: } 0 \text {, no staining; } 1 \text {, faint staining; } 2 \text {, } \\
\text { weak to moderate staining; } 3 \text {, strong } \\
\text { staining. } \\
0 \text {, nuclear and cytoplasmic staining in }<50 \% \\
\text { of cancer cells; } 1+\text {, staining with intensity } 1 \\
\text { in } \geq 50 \% ; 2+\text {, staining with intensity } 2 \text { in } \\
\geq 50 \% ; 3+\text {, staining with intensity } 3 \text { in } \geq 50 \% \text {. } \\
\text { (FGFR } 2 \text { overexpression: } 2+\text { and } 3+\text { ) }\end{array}$ & $\begin{array}{l}295 \\
(31.0 \%)\end{array}$ & $\begin{array}{l}132 \\
(44.7 \%): \\
207 \\
(31.6 \%) \\
p<0.001\end{array}$ & $\begin{array}{l}139(47 \%): \\
216(33 \%) \\
p<0.001\end{array}$ & $\begin{array}{l}89(30.2 \%) \\
: 133 \\
(20.3 \%) \\
p<0.001\end{array}$ \\
\hline $\begin{array}{l}\text { Han } \\
(2015)[28]\end{array}$ & Korea & 2005 & I-IV & 362 & $\begin{array}{l}\text { IHC with TMA } \\
\text { Anti-FGFR2b } \\
\text { MoAb (FPR2-D) }\end{array}$ & $\begin{array}{l}0 \text { or } 1 \text {, no or faint staining or }<10 \% \text { of cells; } \\
2+\text {, weak to moderate staining in } \geq 10 \% ; 3+\text {, } \\
\text { strong complete membranous staining in } \\
\geq 10 \% \\
\text { (FGFR } 2 \text { overexpression: } 2+\text { or } 3+\text { ) }\end{array}$ & $9(2.5 \%)$ & NA & $\begin{array}{l}9(100 \%): \\
239 \\
(67.7 \%) \\
p=0.062\end{array}$ & $\begin{array}{l}8(88.9 \%): \\
162 \\
(45.9 \%) \\
p=0.059\end{array}$ \\
\hline $\begin{array}{l}\text { Ahn } \\
(2016)[29]\end{array}$ & Korea & 1996-2006 & I-IV & 1974 & $\begin{array}{l}\text { IHC with TMA } \\
\text { Primary FGFR2b } \\
\text { Ab (FPR2-D) }\end{array}$ & $\begin{array}{l}\text { Intensity: } 1+, \text { cytoplasmic or membranous } \\
\text { staining under } \times 40 \text { magnification; } 2+, \\
\text { staining in } \times 10 \text { or } \times 20 \text { magnification; } 3+\text {, } \\
\text { strong staining in } \times 4 \text { magnification } \\
\text { (FGFR2 overexpression: intensity score } x \\
\text { percentage of stained tumor cells } \geq 150 \text { ) }\end{array}$ & $73(3.7 \%)$ & $\begin{array}{l}56 \\
(76.7 \%): \\
1253 \\
(65.9 \%) \\
p=0.058\end{array}$ & $\begin{array}{l}65(89 \%): \\
1640 \\
(86.3 \%) \\
p=0.006\end{array}$ & NA \\
\hline $\begin{array}{l}\text { Jia } \\
(2016)[30]\end{array}$ & China & 2011-2012 & I-III & 143 & $\begin{array}{l}\text { IHC with whole } \\
\text { slides } \\
\text { Rabbit antihuman } \\
\text { FGFR2 Ab } \\
\text { (ab10648) }\end{array}$ & $\begin{array}{l}\text { Intensity: } 0 \text {, no staining; } 1 \text {, weak staining; } 2 \text {, } \\
\text { moderate staining; } 3 \text {, strong staining. } \\
\text { Percentage of positive cells: } 0,0 \% \text { positive; } \\
1,<10 \% \text { positive; } 2,10 \%-50 \% \text { positive; } 3, \\
>50 \% \text { positive. } \\
\text { (FGFR } 2 \text { overexpression: intensity score }+ \\
\text { percentage score } \geq 3 \text { ) }\end{array}$ & 49 (34.3\%) & $\begin{array}{l}39 \\
(79.6 \%): \\
55 \\
(58.5 \%) \\
p=0.058\end{array}$ & $\begin{array}{l}29(59.2 \%) \\
: 20 \\
(21.3 \%) \\
p<0.001\end{array}$ & $\begin{array}{l}12(24.5 \%) \\
: 8(8.5 \%) \\
p=0.001\end{array}$ \\
\hline $\begin{array}{l}\text { Tokunaga } \\
(2016)[31]\end{array}$ & Japan & 2000-2014 & I-IV & 176 & $\begin{array}{l}\text { IHC with whole } \\
\text { slides } \\
\text { Mouse } \\
\text { anti-FGFR2 MoAb } \\
\text { (ab58201) }\end{array}$ & $\begin{array}{l}\text { Intensity: } 0 \text {, no staining; } 1 \text {, weak staining, } \\
\text { incomplete membranous staining; } 2 \text {, } \\
\text { moderate staining, complete membranous } \\
\text { staining; } 3 \text {, strong staining. } \\
\text { (FGFR2 overexpression: } \geq 2 \text { ) }\end{array}$ & $\begin{array}{l}108 \\
(61.4 \%)\end{array}$ & $\begin{array}{l}75 \\
(69.4 \%): \\
13 \\
(19.1 \%) \\
p<0.001\end{array}$ & $\begin{array}{l}59(54.6 \%) \\
: 15 \\
(22.1 \%) \\
p<0.001\end{array}$ & NA \\
\hline $\begin{array}{l}\text { Hosoda } \\
(2018)[32]\end{array}$ & Japan & $2000-2010$ & II-III & 172 & $\begin{array}{l}\text { IHC with whole } \\
\text { slides } \\
\text { Mouse } \\
\text { anti-FGFR2 MoAb }\end{array}$ & $\begin{array}{l}0 \text {, staining in }<50 \% \text { of tumor cells; } 1+\text {, faint } \\
\text { cytoplasmic and/or nuclear staining in } \\
\geq 50 \% ; 2+\text {, weak to moderate staining } \geq \text { in } \\
50 \% ; 3+\text {, strong staining in } \geq 50 \% \\
\text { (FGFR2 overexpression: } 3+\text { ) }\end{array}$ & $55(31.9 \%)$ & NA & $\begin{array}{l}51(92.7 \%) \\
: 92 \\
(82.1 \%) \\
p=0.099\end{array}$ & $\begin{array}{l}42(76.4 \%) \\
: 76 \\
(67.9 \%) \\
p=0.283\end{array}$ \\
\hline
\end{tabular}

FGFR, fibroblast growth factor receptor; KGFR, keratinocyte growth factor receptor; IHC, immunohistochemistry; TMA, tissue microarray; MoAb, monoclonal antibody; PoAb, polyclonal antibody; NA, not available 
A

\begin{tabular}{|c|c|c|c|c|c|c|c|c|c|c|}
\hline \multirow[b]{2}{*}{ Study or Subgroup } & \multicolumn{2}{|c|}{ Experimental } & \multicolumn{2}{|c|}{ Control } & & \multirow{2}{*}{$\begin{array}{l}\text { Odds Ratio } \\
\text { M-H. Random. } 95 \% \mathrm{Cl}\end{array}$} & \multirow{2}{*}{\multicolumn{4}{|c|}{$\begin{array}{c}\text { Odds Ratio } \\
\mathrm{M}-\mathrm{H} \text {. Random. } 95 \% \mathrm{Cl}\end{array}$}} \\
\hline & Events & Total & Events & Total & Weight & & & & & \\
\hline Toyokawa (2009) & 38 & 42 & 68 & 94 & $9.6 \%$ & $3.63[1.18,11.19]$ & & & & \\
\hline Murase (2014) & 63 & 114 & 41 & 108 & $18.8 \%$ & $2.02[1.18,3.45]$ & & & $\longrightarrow$ & \\
\hline Nagatsuma (2015) & 136 & 295 & 207 & 655 & $23.7 \%$ & $1.85[1.40,2.45]$ & & & & \\
\hline Ahn (2016) & 56 & 73 & 1253 & 1901 & $18.5 \%$ & $1.70[0.98,2.96]$ & & & - & \\
\hline Jia (2016) & 39 & 49 & 55 & 94 & $13.8 \%$ & $2.77[1.23,6.20]$ & & & & \\
\hline Tokunaga (2016) & 75 & 108 & 15 & 68 & $15.6 \%$ & $8.03[3.97,16.24]$ & & & & \\
\hline Total $(95 \% \mathrm{Cl})$ & & 681 & & 2920 & $100.0 \%$ & $2.63[1.70,4.06]$ & & & & \\
\hline Total events & 407 & & 1639 & & & & & & & \\
\hline $\begin{array}{l}\text { Heterogeneity: } \mathrm{Tau}^{2} \\
\text { Test for overall effect }\end{array}$ & $\begin{array}{l}0.19 ; \mathrm{Chi}^{2} \\
\mathrm{z}=4.33(\mathrm{~F}\end{array}$ & $\begin{array}{l}=16.43 \\
<0.000\end{array}$ & $\begin{array}{l}d f=5(P \\
1)\end{array}$ & $=$ & ); $1^{2}=$ & & 0.01 & $\begin{array}{c}0.1 \\
\text { FGFR2 expression (-) }\end{array}$ & ${ }^{1}$ FGFR2 expr & $\begin{array}{ll}10 & 100 \\
\text { ression }(+) & \end{array}$ \\
\hline
\end{tabular}

B

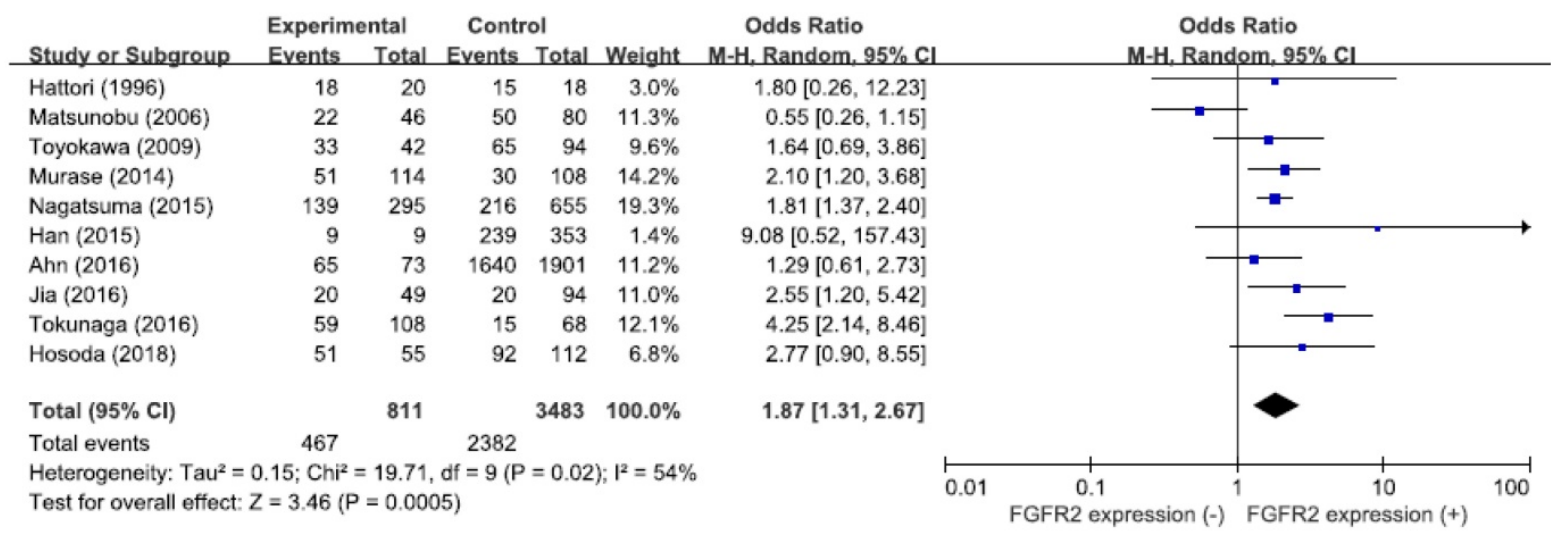

C

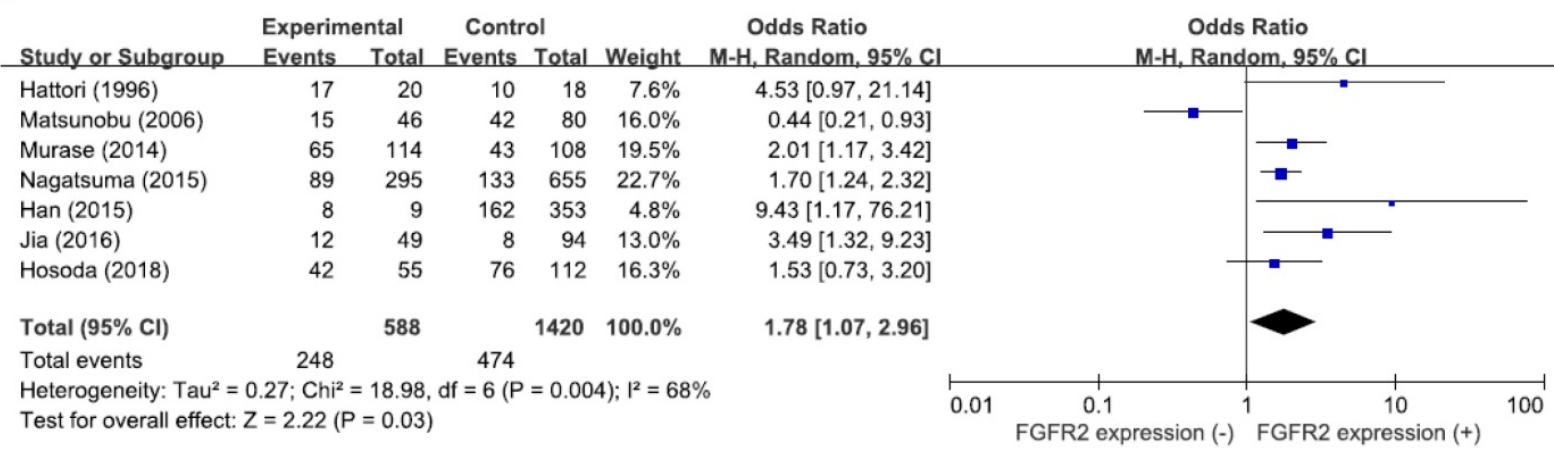

Figure 2. Forest plots of odds ratios for $\mathrm{PT}(\mathrm{A}), \mathrm{LN}$ metastasis (B), and stage (C).

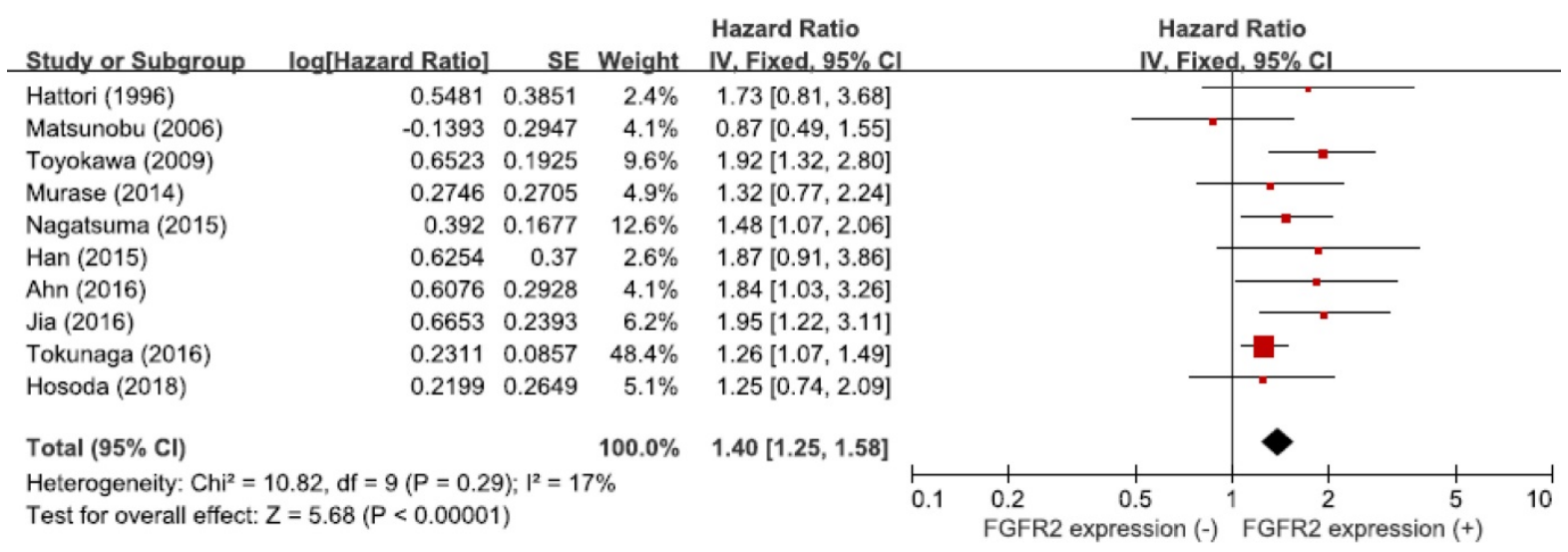


Figure 3. Forest plot of hazard ratios for overall survival.

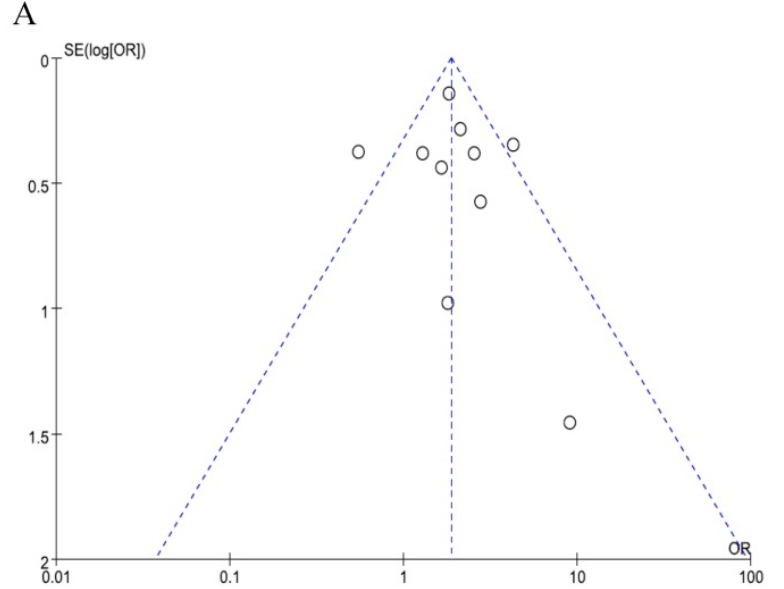

B

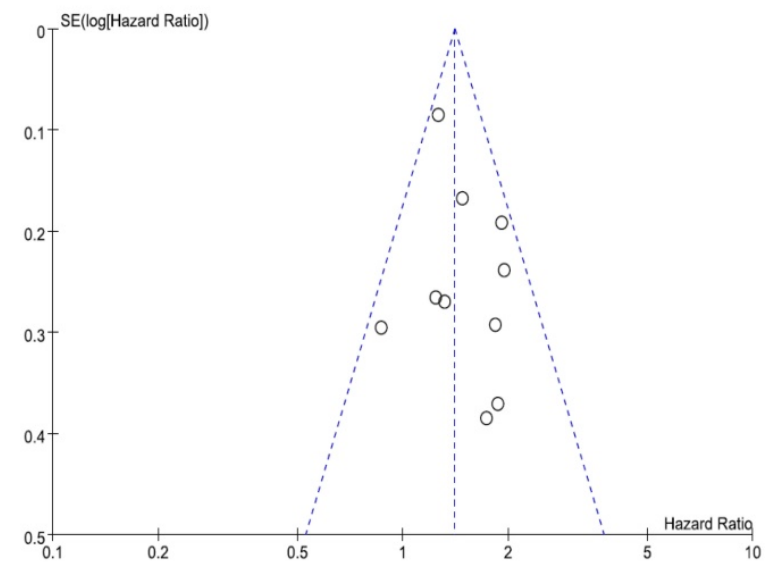

Figure 4. Funnel plots for publication bias regarding $L N$ metastasis $(A)$ and overall survival (B).

\section{Discussion}

The FGF/FGFR signaling pathway is under active investigation as a potential molecular target for advanced GC $[37,38]$. However, the prognostic role of FGFR2 overexpression remains controversial. In the current meta-analysis, we evaluated the pathological and prognostic significance of high FGFR2 expression in patients with GC. To our knowledge, this is the first meta-analysis to provide an in-depth analysis of FGFR2 overexpression in relation with survival of patients with GC.

Dysregulation of the FGFR family signaling has been associated with cancer development and progression in multiple cancers including multiple myeloma, cancers of the bladder, prostate, ovary, stomach, and breast [39-41]. Mechanisms for genetic alteration of FGFR2 include gene amplification, mutations or translocations, receptor overexpression, or autocrine FGF signaling. The FGFR2 gene undergoes alterative splicing in the third immunoglobulin domain, leading to two isoforms of the FGFR2 receptor (IIIb and IIIc) with different ligand binding. In FGFR2-amplified GC, the FGFR2 IIIb isoform, not IIIC, is overexpressed [29,42]. In GC, FGFR2 amplification is significantly associated with FGFR2 overexpression [29,31]. While FGFR2 amplification has been observed in up to 15\% [31], FGFR2 protein by IHC in GC is more frequently overexpressed [31,32]. In the included studies of this meta-analysis, frequencies of FGFR2 overexpression varied from $2.5 \%$ [28] to $61.4 \%$ [31]. The incidence of immunohistochemical expression of FGFR2 protein might differ between histological subtypes according to the Lauren's pathological classification [29]. In the study by Hattori et al., FGFR2 overexpression was detected in 20 of 38 diffuse-type GCs, but in none of 11 intestinal-type lesions [23]. However, Inokuchi et al. failed to observe the significant difference in the incidence of FGFR2 overexpression between diffuse-type GC and intestinal-type GC [33].

Notably, although IHC has been most commonly used to assess FGFR2 expression status, there is no consensus for the IHC methods cut-off criteria to define FGFR2 overexpression [41]. In addition, staining sites (nuclear, cytoplasmic, or membranous staining) for interpretation were various among studies. The prognostic impact of FGFR2 overexpression might be different according to the expression site of FGFR2 protein. In lung cancer, whereas the nuclear FGFR2 overexpression was associated with worse prognosis, the cytoplasmic overexpression was correlated with better outcomes [43]. Therefore, the differences in methodology might be attributable to the wide heterogeneity of FGFR2 expression positivity and the discrepancies in the prognostic role of FGFR2 overexpression among studies.

The clinical significance of FGFR2 overexpression has been investigated in multiple cancers [41,44]. The prognostic impact of FGFR2 overexpression in solid tumors was controversial, with conflicting results among studies. Liu et al. conducted a meta-analysis to evaluate the prognostic role of FGFR2 protein expression [41]. They reported that FGFR2 overexpression was correlated with decreased survival in most solid tumors. However, they included studies evaluating the prognostic significance of not only receptor overexpression but also FGFR2 amplification in the meta-analysis. Thus, the prognostic impact of high FGFR2 expression in GC was inconclusive. In the current study, we systematically evaluated pathological and survival data of 4,294 patients with GC from the ten studies [23-32]. Our meta-analysis revealed that FGFR2 overexpression was significantly associated with 
tumor invasion (pT3-4) $(\mathrm{OR}=2.63,95 \%$ CI: 1.70-4.06, $\mathrm{p}<0.0001)$, $\mathrm{LN}$ metastasis $(\mathrm{OR}=1.87,95 \% \mathrm{CI}$ : 1.31-2.67, $\mathrm{p}<0.0001$ ), and advanced stage (III-IV) (OR $=1.78,95 \%$ CI: 1.07-2.96, $\mathrm{p}=0.03$ ). In addition, patients with FGFR2-overexpressed GC showed significantly worse survival than those with tumors having low FGFR2 expression $(\mathrm{HR}=1.40,95 \% \mathrm{CI}$ : $1.25-1.58, \mathrm{p}<0.00001)$. These results indicate that FGFR2 overexpression is an adverse prognostic factor in patients with GC.

Our study has some inherent limitations. First, the included studies showed differences in the IHC method and cut-off criteria for high FGFR2 expression, disease stage, treatments, and other demographic or clinicopathological data. Second, almost all studies were retrospectively performed and therefore might carry the biases of the retrospective design. Third, all included studies had been performed in Asian countries. Thus, the prognostic significance of FGFR2 overexpression in GC still needs to be verified in Western populations. Finally, the substantial heterogeneity observed among studies could not be completely interpreted although the random-effects model was selected for pooling ORs regarding pathological features.

In conclusion, this meta-analysis and systemic review summarized the existing data regarding FGFR2 expression and survival outcomes in patients with GC. The results indicate that FGFR2 overexpression is associated with poor pathological features and worse survival in GC, suggesting that FGFR2 is a valuable prognostic biomarker as well as a potential therapeutic target. However, large prospective studies using standardized IHC method based on the homogeneous populations are warranted to validate the prognostic significance of FGFR2 expression in patients with GC.

\section{Competing Interests}

The authors have declared that no competing interest exists.

\section{References}

1. Jung KW, Won YJ, Kong HJ, Lee ES; Community of Population-Based Regional Cancer Registries. Cancer statistics in Korea: incidence, mortality, survival, and prevalence in 2015. Cancer Res Treat. 2018; 50: 303-16.

2. Ferlay J, Soerjomataram I, Dikshit R, Eser S, Mathers C, Rebelo M, et al. Cancer incidence and mortality worldwide: sources, methods and major patterns in GLOBOCAN 2012. Int J Cancer. 2015; 136: 359-86.

3. Lim DH, Kim DY, Kang MK, Kim YI, Kang WK, Park CK, et al. Patterns of failure in gastric carcinoma after D2 gastrectomy and chemoradiotherapy: a radiation oncologist's view. Br J Cancer. 2004; 91: 11-7.

4. Yoo CH, Noh SH, Shin DW, Choi SH, Min JS. Recurrence following curative resection for gastric carcinoma. Br J Surg. 2000; 87: 236-42.

5. Wagner AD, Grothe W, Haerting J, Kleber G, Grothey A, Fleig WE. Chemotherapy in advanced gastric cancer: a systematic review and meta-analysis based on aggregate data. J Clin Oncol. 2006; 24: 2903-9.

6. Cunningham D, Starling N, Rao S, Iveson T, Nicolson M, Coxon F, et al. Capecitabine and oxaliplatin for advanced esophagogastric cancer. N Engl J Med. 2008; 358: 36-46.
7. Bang YJ, Van Cutsem E, Feyereislova A, Chung HC, Shen L, Sawaki A, et al. Trastuzumab in combination with chemotherapy versus chemotherapy alone for treatment of HER2-positive advanced gastric or gastro-oesophageal junction cancer (ToGA): a phase 3, open-label, randomised controlled trial. Lancet. 2010; 376: 687-97.

8. Wilke H, Muro K, Van Cutsem E, Oh SC, Bodoky G, Shimada Y, et al. Ramucirumab plus paclitaxel versus placebo plus paclitaxel in patients with previously treated advanced gastric or gastro-oesophageal junction adenocarcinoma (RAINBOW): a double-blind, randomised phase 3 trial. Lancet Oncol. 2014; 15: 1224-35.

9. Kang YK, Boku N, Satoh T, Ryu MH, Chao Y, Kato K, et al. Nivolumab in patients with advanced gastric or gastro-oesophageal junction cancer refractory to, or intolerant of, at least two previous chemotherapy regimens (ONO-4538-12, ATTRACTION-2): a randomised, double-blind, placebo-controlled, phase 3 trial. Lancet. 2017; 390: 2461-71.

10. Xie L, Su X, Zhang L, Yin X, Tang L, Zhang X, et al. FGFR2 gene amplification in gastric cancer predicts sensitivity to the selective FGFR inhibitor AZD4547. Clin Cancer Res. 2013; 19: 2572-83.

11. Nakamura K, Yashiro M, Matsuoka T, Tendo M, Shimizu T, Miwa A, et al. A novel molecular targeting compound as K-samII/FGF-R2 phosphorylation inhibitor, Ki23057, for Scirrhous gastric cancer. Gastroenterology. 2006; 131: 1530-41.

12. Bai A, Meetze K, Vo NY, Kollipara S, Mazsa EK, Winston WM, et al. GP369, an FGFR2-IIIb-specific antibody, exhibits potent antitumor activity against human cancers driven by activated FGFR2 signaling. Cancer Res. 2010; 70: 7630-9.

13. Brooks AN, Kilgour E, Smith PD. Molecular pathways: fibroblast growth factor signaling: a new therapeutic opportunity in cancer. Clin Cancer Res. 2012; 18: 1855-62.

14. Eswarakumar VP, Lax I, Schlessinger J. Cellular signaling by fibroblast growth factor receptors. Cytokine Growth Factor Rev. 2005; 16: 139-49.

15. Dailey L, Ambrosetti D, Mansukhani A, Basilico C. Mechanisms underlying differential responses to FGF signaling. Cytokine Growth Factor Rev. 2005; 16: 233-47.

16. Grose R, Dickson C. Fibroblast growth factor signaling in tumorigenesis. Cytokine Growth Factor Rev. 2005; 16: 179-86.

17. Turner N, Grose R. Fibroblast growth factor signaling: from development to cancer. Nat Rev Cancer. 2010; 10: 116-29.

18. Yoshino M, Ishiwata T, Watanabe M, Matsunobu T, Komine O, Ono Y, et al. Expression and roles of keratinocyte growth factor and its receptor in esophageal cancer cells. Int J Oncol. 2007; 31: 721-8.

19. Matsuda Y, Ishiwata T, Yamahatsu K, Kawahara K, Hagio M, Peng WX, et al. Overexpressed fibroblast growth factor receptor 2 in the invasive front of colorectal cancer: a potential therapeutic target in colorectal cancer. Cancer Lett. 2011; 309: 209-19.

20. Cho K, Ishiwata T, Uchida E, Nakazawa N, Korc M, Naito Z, et al. Enhanced expression of keratinocyte growth factor and its receptor correlates with venous invasion in pancreatic cancer. Am J Pathol. 2007; 170: 1964-74.

21. Lee HJ, Kang HJ, Kim KM, Yu ES, Kim KH, Kim SM, et al. Fibroblast growth factor receptor isotype expression and its association with overall survival in patients with hepatocellular carcinoma. Clin Mol Hepatol. 2015; 21: 60-70.

22. Sun $S$, Jiang $Y$, Zhang $G$, Song $H$, Zhang $X$, Zhang $Y$, et al. Increased expression of fibroblastic growth factor receptor 2 is correlated with poor prognosis in patients with breast cancer. J Surg Oncol. 2012; 105: 773-9.

23. Hattori $\mathrm{Y}$, Itoh $\mathrm{H}$, Uchino $\mathrm{S}$, Hosokawa $\mathrm{K}$, Ochiai $\mathrm{A}$, Ino $\mathrm{Y}$, et al. Immunohistochemical detection of K-sam protein in stomach cancer. Clin Cancer Res. 1996; 2: 1373-81.

24. Matsunobu T, Ishiwata T, Yoshino M, Watanabe M, Kudo M, Matsumoto K, et al. Expression of keratinocyte growth factor receptor correlates with expansive growth and early stage of gastric cancer. Int J Oncol. 2006; 28: 307-14.

25. Toyokawa T, Yashiro M, Hirakawa K. Co-expression of keratinocyte growth factor and $\mathrm{K}$-sam is an independent prognostic factor in gastric carcinoma. Oncol Rep. 2009; 21: 875-80.

26. Murase H, Inokuchi M, Takagi Y, Kato K, Kojima K, Sugihara K. Prognostic significance of the co-overexpression of fibroblast growth factor receptors 1, 2 and 4 in gastric cancer. Mol Clin Oncol. 2014; 2: 509-17.

27. Nagatsuma AK, Aizawa M, Kuwata T, Doi T, Ohtsu A, Fujii H, et al. Expression profiles of HER2, EGFR, MET and FGFR2 in a large cohort of patients with gastric adenocarcinoma. Gastric Cancer. 2015; 18: 227-38.

28. Han N, Kim MA, Lee HS, Kim WH. Evaluation of Fibroblast Growth Factor Receptor 2 Expression, Heterogeneity and Clinical Significance in Gastric Cancer. Pathobiology. 2015; 82: 269-79.

29. Ahn S, Lee J, Hong M, Kim ST, Park SH, Choi MG, et al. FGFR2 in gastric cancer: protein overexpression predicts gene amplification and high H-index predicts poor survival. Mod Pathol. 2016; 29: 1095-103.

30. Jia YX, Li TF, Zhang DD, Fan ZM, Fan HJ, Yan J, et al. The coexpression and prognostic significance of c-MET, fibroblast growth factor receptor 2, and human epidermal growth factor receptor 2 in resected gastric cancer: a retrospective study. Onco Targets Ther. 2016:9:5919-29.

31. Tokunaga R, Imamura Y, Nakamura K, Ishimoto T, Nakagawa S, Miyake K, et al. Fibroblast growth factor receptor 2 expression, but not its genetic amplification, is associated with tumor growth and worse survival in esophagogastric junction adenocarcinoma. Oncotarget. 2016; 7: 19748-61. 
32. Hosoda K, Yamashita K, Ushiku H, Ema A, Moriya H, Mieno H, et al. Prognostic relevance of FGFR2 expression in stage II/III gastric cancer with curative resection and S-1 chemotherapy. Oncol Lett. 2018; 15: 1853-60.

33. Inokuchi M, Murase H, Otsuki S, Kawano T, Kojima K. Different clinical significance of FGFR1-4 expression between diffuse-type and intestinal-type gastric cancer. World J Surg Oncol. 2017; 15: 2

34. Kim ST, Ahn S, Lee J, Lee SJ, Park SH, Park YS, et al. Value of FGFR2 expression for advanced gastric cancer patients receiving pazopanib plus CapeOX (capecitabine and oxaliplatin). J Cancer Res Clin Oncol. 2016; 142: 1231-7.

35. Eagger M, Davey Smith G, Schneider M, Minder C. Bias in meta-analysis detected by a simple graphical test. BMJ. 1997; 315: 629-34

36. Sterne JA, Sutton AJ, Ioannidis JP, Terrin N, Jones DR, Lau J, et al. Recommendations for examining and interpreting funnel plot asymmetry in meta-analyses of randomised controlled trials. BMJ. 2011; 343: d4002.

37. Hierro C, Alsina M, Sánchez M, Serra V, Rodon J, Tabernero J. Targeting the fibroblast growth factor receptor 2 in gastric cancer: promise or pitfall? Ann Oncol. 2017; 28: 1207-16.

38. Gavine PR, Mooney L, Kilgour E, Thomas AP, Al-Kadhimi K, Beck S, et al. AZD4547: an orally bioavailable, potent, and selective inhibitor of the fibroblast growth factor receptor tyrosine kinase family. Cancer Res. 2012; 72: 2045-56.

39. Su X, Zhan P, Gavine PR, Morgan S, Womack C, Ni X, et al. FGFR2 amplification has prognostic significance in gastric cancer: results from a large international multicentre study. Br J Cancer. 2014; 110: 967-75.

40. Chang J, Liu X, Wang S, Zhang Z, Wu Z, Zhang X, et al. Prognostic value of FGFR gene amplification in patients with different types of cancer: a systematic review and meta-analysis. PLoS One. 2014; 9: e105524.

41. Liu G, Xiong D, Xiao R, Huang Z. Prognostic role of fibroblast growth factor receptor 2 in human solid tumors: A systematic review and meta-analysis. Tumour Biol. 2017; 39: 1010428317707424.

42. Bai A, Meetze K, Vo NY, Kollipara S, Mazsa EK, Winston WM, et al. GP369, an FGFR2-IIIb-specific antibody, exhibits potent antitumor activity against human cancers driven by activated FGFR2 signaling. Cancer Res. 2010; 70: 7630-9.

43. Behrens C, Lin HY, Lee JJ, Raso MG, Hong WK, Wistuba II, et al. Immunohistochemical expression of basic fibroblast growth factor and fibroblast growth factor receptors 1 and 2 in the pathogenesis of lung cancer. Clin Cancer Res. 2008; 14: 6014-22.

44. Templeton AJ, Diez-Gonzalez L, Ace O, Vera-Badillo F, Seruga B, Jordán J, et al. Prognostic relevance of receptor tyrosine kinase expression in breast cancer: a meta-analysis. Cancer Treat Rev. 2014; 40: 1048-55. 